\title{
Türk Bankalarında Dijital Bankacılık Uygulamalarının İnsan Kaynakları Stratejileri Kapsamında İşe Alımlar Üzerine Bir Tahmin
}

\author{
Öğr. Gör. Dr. Perihan Tüzün ${ }^{1^{*}}$
}

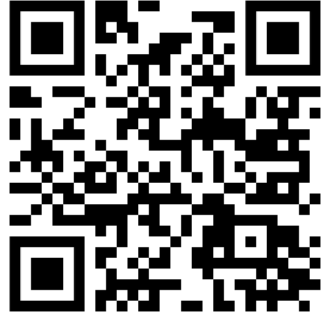

Gelis tarihi: 23.10.2020

Kabul tarihi: 19.11.2020

\section{Atıf bilgisi:}

IBAD Sosyal Bilimler Dergisi

Sayı: Özel Sayı Sayfa: 433-452

Yıl: 2020

This article was checked by Turnitin. Similarity Index $11 \%$

Bu makalede araştırma ve yayın etiğine uyulmuştur.

1 Isparta Uygulamalı Bilimler Üniversitesi, Türkiye,
ORCID ID 0000-0003-3245-2100
ÖZ

Teknoloji yoğunluğunun en fazla hissedildiği sektörlerden biri olan bankacılık sektörünün, bas döndüren hızla yaşanan teknolojik gelișmeleri hizmetlere kısa sürede dönüştürebildiği bilinen bir gerçektir. Bankacıllk sektöründe, müşteri talepleri ve küresel konjonktürün gerektirdiği hizmetleri sunabilmek ve çağın gerisinde kalmamak için sürekli bir rekabet söz konusudur. Bu rekabette teknoloji yatırımları her ne kadar önemli ise de, insan kaynağı kullanımı önemini hala koruyan bir husustur. Bu çalışmada, Türk Bankacilık sektöründe faaliyet gösteren bankalara ait toplam şube sayısı, toplam çalışan sayısı, ATM sayısı, telefon bankacılığına gelen çağrı sayısı, internet bankacılığı kullanıcı sayısı, mobil bankacılık kullanıcı sayısı gibi parametreler kullanılarak, ileriki döneme ait tahminlerde bulunulmuștur. $\mathrm{Bu}$ tahminlerden yola çıkarak bankaların insan kaynakları stratejilerinde işe alımın ne yönde olabileceği tartışılmıştır.

Anahtar Kelimeler: Dijital Bankacılık, Çalıșan Sayısı, İnsan Kaynakları Stratejileri, Gri Tahminleme.

* Sorumlu Yazar 


\section{An Estimation of Digital Banking Practices in Turkish Banks on Recruitments Under Human Resources Strategies}

\section{Lec. Dr. Perihan Tüzün ${ }^{1^{*}}$}

First received: 23.10 .2020

Accepted: 19.11.2020

\section{Citation:}

IBAD Journal of Social Sciences

Issue: Special Issue Pages:433-452

Year: 2020

This article was checked by Turnitin. Similarity Index 11\%

1 Isparta University of Applied Sciences, Turkey, perihantuzun@isparta.edu.tr,

ORCID ID 0000-0003-3245-2100

* Corresponding Author

\begin{abstract}
It is a known fact that the banking sector, which is one of the sectors where the technology intensity is felt the most, can transform the technological developments experienced with dizzying speed into services in a short time. In the banking sector, there is a constant competition in order to provide the services required by customer demands and the global conjuncture for not to stay behind the times. Although technology investments are important in this competition, the use of human resources is still an important issue. In this study, using parameters such as the total number of branches belonging to banks operating in the Turkish banking sector, the total number of employees, the number of ATMs, the number of incoming calls to telephone banking, the number of internet banking users, and the number of mobile banking users, the exact numbers for the future period are calculated. Based on these estimates, it was discussed how the recruitment might be estimated in the human resources strategies of the banks.
\end{abstract}

Keywords: Digital Banking, Number of staff, HRM Strategies, Grey System Theory. 


\section{GİRIŞ}

Günümüzde yoğun olarak kullanılan teknoloji, durağanlıktan uzak, anlık gelişmeleri içinde barındıran bir hâl almıştır. Bu yönüyle de teknoloji yoğun iş yapan sektörlerin gelişmeleri yakından takip etmesi ve her an kendilerini güncellemesi zorunlu hale gelmiştir. Bankacılık sektörü, pazarlama, teknoloji ve insan kaynağının her üçünü de yoğun olarak kullanan bir sektördür. Bankaların çalışma stratejileri, başka etkenlerin yanında, bu üçlü yapının etkisiyle şekillenmektedir. Yakın bir geçmişe kadar, "bankaların alternatif dağıtım kanalları" dendiğinde aklımıza telefon bankacılığı, otomatik para makinaları (ATM), internet bankacılığı gelmekte iken, şu anda yine internet alt yapısı ile kullanılmakta olan ve mobil cihazlarda işlerliği bulunan mobil bankacılık uygulamaları sıklıkla kullanılmaya başlanmıştır. Bunun yanında, bankaların pazarlama faaliyetlerinin de bu yöne yöneldiği, yazılı ve görsel basın, sosyal medya gibi kanallarla bankaların mobil bankacılık uygulamalarının kullanılması için yönlendirme yaptıkları bilinen bir gerçektir.

Bankacılık, ülkemiz toplumu gibi toplumlarda, kişilerden bağımsız düşünülemez. Müşteri açısından, kimi zaman bankanın kendisi değil, müşteri temsilcisinin kim olduğu daha önemli hale gelebilmektedir. Şüphesiz, bu duruma sebep, karşısındaki kişiye duyulan güven ve geçmişten bu yana süregelen bankac1müşteri ilişkisidir. Çoğu zaman, banka çalışanının, bulunduğu bankadan farklı bir kurumda bankacılık yapmaya devam etmesi, müşteri ile olan ilişkisini yeni kurumunda da devam ettirmesi sonucunu doğurmaktadır. Büyük şehirler de dâhil olmak üzere, tecrübeli çalışan alımlarında belirli bir müşteri portföyüne sahip olan çalışanların tercih sebebi olması, sektör içerisinde teamül halini almıştır. Teknoloji ile birlikte düşünüldüğ̈̈nde, bankaların insan kaynakları stratejilerinde işe alımla ilgili bir takım değişiklikler de meydana gelmiştir. Günümüzde teknolojiyi bilen ve kullanabilen, nitelikli, yeniliklere hızla uyum sağlayabilen çalışanlar tercih edilmeye başlanmıştır. Dijital kanalların etkinliğinin giderek artması, şube çalışanından ziyade "Bilgi Teknolojileri" bölümlerine insan kaynağı ihtiyacında artış göstermiştir.

Çalışmada, bankaların dijital bankacılık uygulamalarının neler olduğu, nasıl kullanıldığı ve bankalara yansıyan maliyetleri, müșterilere yansıyan maliyetleri, olumlu yönleri ve olumsuz yönleri tartışılacak, insan kaynakları yönetim stratejilerinin biçimlerine ve önemine değinilecektir. Bu çalışmada, 2011-2017 yılları arasındaki Türkiye'de faaliyet gösteren toplam banka sayısı, toplam şube sayısı, toplam ATM sayısı, bankaların çağrı merkezleri aracılığıyla alınan toplam gelen çağrı sayısı, toplam aktif internet bankacıllı̆ı ve toplam aktif mobil bankacılık kullanıcı sayısı temelinde Gri Tahmin yöntemlerinden en çok tercih edilen GM(1,1) Metodu kullanılarak, 2018-2023 yılları arasındaki değerleri tahmin edilmiştir. Elde edilen tahmini değerlere göre bankaların insan kaynakları stratejilerindeki işe alım konusunda ne gibi değişikliklere yol açacağı tartışılmıştır.

\section{LITERATÜR TARAMASI}

Araştırma literatürü, müşterilerin bankacılık teknolojilerine yönelik tutumlarını anlamayı ve böylece gelişimsel planlama ve pazarlama için çıkarımlar sağlamayı amaçlayan birçok çalışma barındırmaktadır (Sundarraj ve Wu, 2005, s. 427). Dijital bankacılık uygulamalarından bahsedildiğinde ilk akla gelen araç olan ATM'ler ile ilgili alan yazında birçok çalışma bulunmaktadır. ATM, bankacılığın şube dışına taşınması için ilk ortaya çıkan uygulamalardan biridir. Ancak yapılan çalıșmaların çoğu insan kaynakları stratejileri ile ilgili değildir (Hatta ve Liyama, 1991; Rogers ve Walker, 1996; Ojeka ve Ikpefan, 2011; Korkmaz vd., 2015; Koca, 2018). Genel olarak, banka kârlılığı, müşteriler açısından avantajlar ve ATM ile ilgili güvenlik konularına değinildiği görülmüş̧ür.

Telefon bankacılığı konusunda, bilgi teknolojileri, müşteri tanıma prosedürleri, müşterilerin şube dış1 bankacılık kanallarına uyum süreçleri, banka karlılığına katkısı, SMS ile doğrulama işlemleri gibi çeşitli konular ile ilgili çalışmalar bulunmaktadır (Edwards, Quinn, Dalziel ve Jack, 1997; Ahmad ve Buttle, 2002; Sundarraj ve Wu, 2005; Gunson, Marshall, Morton ve Jack, 2011; Peevers, Douglas, Marshall ve Jack, 2011; Alikhani, Azad, Mousavi ve Mahmoudzadeh, 2013). Telefon bankacıllğı çağrı merkezi çalışanlarında yapılan araştırmaların başında çalışanların sağlık problemleri ile ilgili incelemeler bulunmaktadır (Halford ve Cohen, 2003; Sri ve Panchanatham, 2012; Ansaloni, vd., 2014; Poochada ve Chaiklieng, 2015; Chang, Zivin, Gross ve Neidell, 2019). Lin ve arkadaşları (2010), Tayvan'daki bir 
bankada çağrı merkezi çalışanları için algılanan iş stresi ve sağlık durumunun nasıl farklılaştığını ve ayrıca gelen (gelen aramalar) ve giden (giden aramalar) arama etkinlikleriyle olan ilişkilerini araştırmıştır. Örnek banka, anket sırasında yaşları 19 ile 54 arasında değişen 289 çağrı merkezi çalışandan veriler toplanmıştır. Veriler, bireysel faktörler, sağlık şikâyetleri, algılanan düzey iş stresi ve başlıca iş stres faktörleri gibi konular hakkında değerlendirilmiş ve çağrı merkezi çalışanlarının algıladıkları stres düzeyinin sağlıklarını derin olarak etkilediği ortaya koyulmuştur.

İnternet bankacılığı, hem kurumsal hem de bireysel müşteriler tarafindan yaygın olarak kullanılan bir uygulama olduğundan, literatürde çok fazla internet bankacılığı konusunu içeren çalışma bulunmaktadır. $\mathrm{Bu}$ çalışmaların bir kısmı teknik altyapılar ve güvenlikle ilgiliyken, diğer kısmı genellikle, internet bankacılı̆̆ının müşteriler tarafından benimsenmesi (Furst, Lang ve Nolle, 2002; Cheng, Lam ve Yeung, 2006; Safeena, Date, Kammani ve Hundewale, 2012; Hanafizadeh, Behboudi, Koshksaray ve Tabar, 2014; Yurttadur ve Süzen, 2016; Teka, 2017; Rahi, Ghani ve Ngah, 2020; Lin, Wang ve Hung, 2020) konusu hakkındadır. Bunun dışında, banka karlılığı ve yönetime etkileri (Daniel ve Storey, 1997; Siam, 2006; Driga ve Isac, 2014; Felix, 2014; Roy, 2018), müşteri memnuniyeti (Uzundağ, 2013; John ve Rotimi, 2014) gibi konular araştırılmıştır. Ayrıca banka çalışanlarının internet bankacılığı ya da diğer elektronik bankacılık kanalları nedeniyle yaşamış oldukları iş güvenliği sorunları (Adelani, 2019; Ahmed ve Rahman, 2020; Khattab, Ahmed ve Al-Magli, 2020) hakkında çalışmalar bulunmaktadır.

İnternet bankacılığı ve mobil bankacılık uygulamaları, aynı amaçla kullanılmaları nedeniyle akademik çalışmalar genellikle her iki başlı̆ı da kapsar şekilde gerçekleştirilmiştir. Bazı çalışmalarda ise, internet bankacılı̆ğ ve mobil bankacılığın her ikisi de kast edilerek elektronik bankacılık ifadesi kullanılmıştır. Mobil bankacılık ya da elektronik bankacılık başlığı altında yapılmış olan çalışmalar incelenmiştir. Sardana ve Singhania (2018), yapmış oldukları çalışmada dijital bankacılık uygulamalarının tamamından söz ederek, mevcut durumu ortaya koymak amaciyla bir literatür araştırması gerçekleştirmiştir. Başta internet bankacılığı ve mobil bankacılık olmak üzere, ATM, Debit Kart (banka kartı), EFT (Elektronik Fon Transferi) gibi başlıklar ele alınmıștır. Aynı șekilde Shaikh ve Karjaluoto (2015), literatür araştırması olarak gerçekleştirdikleri araştırmada genellikle mobil bankacılık uygulamalarının teknoloji kabulü ve kullanıcının yaşam tarzı ve kullandığı akıllı cihazın özellikleri ile uyumlu olduğunu belirtmiştir. Mishra ve Bisht (2013), Hindistan'da yapmış oldukları araştırmada mobil bankacılığın geliştirilmesi için, finans kurumları, telekomünikasyon kuruluşları, düzenleyici ve denetleyici kurumların yanında müşterilerin de sürece dâhil edilerek gelişme sağlanabileceğini önermiştir. Afshan ve Sharif (2016), mobil bankacılığın benimsenmesi hakkında yaptıkları çalışmada, mobil bankacılık kabulünün davranışsal, çevresel ve teknolojik boyutlarını analiz etmiştir. Sonuç olarak, davranışsal, çevresel ve teknolojik özelliklerin mobil bankacılığın kabullenilmesinde etkisinin olduğunu ortaya koymuştur. Erol, Çınar ve Duramaz (2015), yaptıkları çalışmada, elektronik bankacılık gelişiminin banka kârlılığı üzerine etkilerini incelemiştir. 2006-2012 arası dönem için, banka kârlılıklarının faiz dışı gelirlerinde (işlem ücretleri vs.) \%1,12'lik bir artışın söz konusu olduğunu belirtmiştir. Elektronik bankacılık hizmetleri ile ilgili yapılmış bir diğer çalışmada, elektronik bankacılık uygulamalarının, hız, güvenlik, etkinlik ve maliyet avantajı yanı sıra kullanıcı ve müșteri memnuniyeti açısından geldiği nokta değerlendirilmiștir (Aytar, Yeğen ve Erdemir, 2012). Aynı şekilde, Erben Yavuz ve Babuşçu (2018), elektronik bankacılık uygulamalarının bankalara sağlamış olduğu avantajlar ile ilgili çalışmasında, ciddi oranda maliyet avantajı sağlaması ve müşteriler açısından da zaman tasarrufu sağladığından söz etmiştir. Elektronik bankacılık uygulamalarının, hukuki açıdan değerlendirilmesi ile ilgili çalışmalar da bulunmaktadır (Lawack-Davis, 2012).

Bankaların insan kaynakları yönetim stratejileri ile ilgili literatür araştırıldığında Malatya'da faaliyet gösteren banka şubesi çalışanları üzerinde gerçekleştirilmiş bir çalışmada, kariyer yönetimi çerçevesinde, kariyer planlaması, kariyer geliştirilmesi vb. konular incelenmiştir. Çalışma sonucunda ilgili banka şubelerinin \%76'sında kariyer yönetim faaliyetlerinin uygulandığı ve uygulamanın en önemli nedenlerinin çalışanların yönetime dâhil edilmesi ve kaliteli bir yönetim örneği sergilemek olduğu bulunmuştur (Deniz ve Ünal, 2007). Gürbüz, Kumkale ve Oğuzhan (2013) çalışmalarında, Trakya bölgesinde 20 bankada çalışan 382 banka çalışanından elde edilen veriler ışığında, çalışan güçlendirme uygulamalarının banka çalışanlarında örgütsel bağlılığı artırdığı sonucuna ulaşmıştır. Koçak ve Erdoğan (2011) tarafından yapılan çalışmada toplam 5 bankada 10 kişi ile görüşülmüştür. Çalışanın seçimi, 
eğitim ve kariyer süreçleri, insan kaynakları süreçlerinde şubelere yetki verip vermediği, sendikalaşma gibi konular ele alınmıştır. Çalışma sonucunda, genel olarak bankaların sendikalaşmaya olumlu bakmadıkları, müşteri memnuniyeti önemsendiği için, çalışanlara karşı tutumlar ve eğitim desteklerinin olumlu olduğu bulunmuştur. Yıldız (2011), Türk bankacılık sektöründeki bir özel mevduat bankasının 421 yöneticisi üzerinde gerçekleştirdiği araştırmasında, insan, yapısal ve müşteri sermayesi unsurlarından oluşan entelektüel sermayenin, bankaların hem sübjektif (algılanan) hem de objektif (nicel) performansını olumlu yönde etkilediğini bulmuştur. Majumder (2012), Bangladeş’te banka çalışanları üzerinde yapmış olduğu araştırmada, bankaların insan kaynakları yönetimi uygulamalarının, özel bankalarda çalışanları eşit derece memnun etmediğini bulmuştur. Çalışanların çoğu ücret, ödül ve motivasyon, kariyer gelişimi, eğitim gibi konulardan memnun olmadığından bankaların insan kaynakları uygulamalarının geliştirilmesi gerektiğini önermiştir. Bahsedilen çalışmaların yanında, bankacılık sektöründe uygulanan insan kaynakları yönetim tarzları (Bartel, 2004; Yurdatapan, 2011; Tondre, 2015; Prakash, 2015), çalş̧an eğitimi ve kariyer gelişimi (Çerik ve Bozkurt, 2010; Özçelik ve Akçay, 2019), yetenek yönetimi ve performans (Cantekinler, 2007; Altunoğlu, Atay ve Terlemez, 2015), istihdam (Ayan, 2012), kayırmacılık (Büte, 2011), iş tatmini (Gürbüz, 2011) gibi birçok farklı konuda ulusal ve uluslararası çalışma bulunmaktadır.

Bu çalışmanın çıkış noktası olan dijital bankacılık uygulamalarının bankaların insan kaynakları yönetimi stratejilerine olası etkileri ile ilgili bir keşif çalışması niteliğinde olan Latif, Mahmood ve Ali (2020)'nin araştırması nitel olarak kurgulanmış bir çalışmadır. İnsan kaynakları uygulayıcıları ile bazı derinlemesine görüşmeler yapılmış ve bir bankacılık örgütünde meydana gelen insan kaynakları yönetimi değişikliklerinin bağlamı ve doğası hakkında belgeler analiz edilmiştir. Çalışma sonucunda insan kaynakları yönetimi işlevinin değişen ve gelişen rolünün ortaya çıkan üç tema ortaya koyulmuştur. Yeni bankacılık işlevlerinin çeşitli yeteneklerle çalışanlara aşılanması, çevik çalışma (yeniliğe uyum sağlama) kültürünü harekete geçirmenin önemi ve çalışanların veri ve teknolojiyi kullanma deneyimine artan odaklanmasının sağlanması bu üç temayı ifade etmektedir.

\section{KAVRAMSEL ÇERÇEVE}

$\mathrm{Bu}$ bölümde bankacılıkta insan kaynakları yönetimi, bankalarda dijital (elektronik) bankacılık uygulamaları ve Gri Tahmin yöntemlerinden $\operatorname{GM}(1,1)$ modeli hakkında bilgi verilmektedir.

\section{Bankacılıkta İnsan Kaynakları Yönetimi}

Bankacılık sektöründe eğitimli, vasıflı ve hızla gelişen bilgi ve iletişim teknolojileri becerisine sahip çalışanlara duyulan ihtiyaç açık bir şekilde görülmektedir. Uygun insan kaynakları yönetimi politikaları ile artan rekabet ortamında mevcut çalışanların elde tutulması ve yeni gelişmelere entegre edilmesi, bankaların rekabet kabiliyetlerini ve müşteri memnuniyetlerini artırmalarını sağlamaktadır (Koçak ve Erdoğan, 2011, s. 260-263).

Bartel (2004)'e göre hizmet sektörü üç önemli noktada üretim sektöründen farklılaşmaktadır. Hizmet sektöründe, somut bir maldan söz etmek mümkün değildir, aynı anda üretilip tüketilme eğilimindedir ve tüketiciyi üretim ve teslimata dâhil eder. İnsan kaynakları yönetimi, hizmet sektörünün büyük bir parçası olan bankalarda oldukça etkili bir rol oynar. İnsan kaynağının yönetimi ve risk yönetimi, bankaların yüz yüze geldiği iki temel zorluktur. Bankaların insanları ve riski nasıl yönettiği, başarılarını belirlemektedir. Yetenekli ve etkin insan gücü olmadan, riskin yönetilmesi de mümkün değildir (Tondre, 2015, s. 130).

Bankacılıkta Insan Kaynakları Yönetiminin Önemi: Örgütlerin verimli bir biçimde çalışabilmesi, örgütleri oluşturan çalışanın etkili yönetilmesine ve onlardan yararlanabilme derecesine bağlıdır (Deniz ve Ünal, 2007, s. 103). Bu nedenle, geçmişte olduğu gibi, bu konuyla ilgilenen örgüt içerisindeki birimler artık "personel" bölümleri değil, "İnsan Kaynakları" olarak adlandırılan bölümler halini almıştır. Şüphesiz, bu sadece bir isim değişikliğinden ibaret olmamış, çalıştırılan insan kaynağına gereksinimle örgüt içerisinde başlayan süreç, çalışanın işe başlatılmasıyla son bulmayan ve çalışan işe devam ettiği sürece devam eden bir hal almıştır.

Geçmişte işyeri kalitesi; teknoloji, makine-teçhizat, işyerinin diğer çevresiyle alakalı olanaklar iken, günümüzde ilk başta bu olanakların sağlanmış olması olağan kabul edilmektedir. İnsan kaynağına 
atfedilen önem birinci planda yer almaya başladığı için, her firmanın fark yaratacağı alan insan kaynağını yönetme biçimi haline gelmiştir. Örgütün sahip olduğu değerler ve örgüt kültürü bir örgütten diğerine kolayca taşınamamaktadır, dolayısıyla her örgütün kendine özgü bir insan kaynağı stratejisi olması olağandır (Koçak ve Erdoğan, 2011, s. 261).

Bankaların bugüne kadar tanık oldukları büyük ölçüde hizmet temelli rekabetin aksine, rekabet artık yoğun olarak teknoloji tabanlı rekabet şeklinde kendini göstermektedir. Teknolojik olarak iyi donanımlı, yapısal olarak yalın ve sermayesi kuvvetli yeni bankaların ortaya çıkması, sunulan hizmetlerin çeşitliliği ve maliyeti ile müşteri beklentilerinin karşılanma hızı ve verimliliği açısından piyasalarda fark yaratacaktır. Yoğun rekabetin yaşandığı bir piyasada ayakta kalabilmek için bankaların verimlilik açısından ölçüm yapması gerekir. Her banka için iç ve dış piyasa ile ilgili rekabet verimliliği açısından büyük bir fark yaratan önemli bir faktör, insan kaynakları faktörüdür (Prakash, 2015, s. 95). Teknolojiyi en iyi kullananlar, genç ve eğitim seviyesi yüksek olan kesim olarak karşımıza çıktığı için, bankaların daima sistem alt yapısı ve insan kaynağı ile müşterilerinden bir adım önde olmaları gerekmektedir. Aksi takdirde rekabet güçlerini kaybedecekleri açıktır. Bankalar, insan kaynakları yönetimi konusunda, yapılarındaki kurumsallığın da etkisi ile nitelikli eleman çalıştırma konusunda oldukça başarılıdır. Ancak işe alım süreci sonrasında da, çalışan motivasyonu ve meslek gelişimleri ile ilgili destek ve eğitimler sayesinde gerek çalışanların motivasyonunu artırmaya, gerekse iş yapış biçimlerini geliştirmeye çaba sarf etmelidir.

Bankacılıkta İnsan Kaynakları Yönetimi Stratejileri Kapsamında İşe Alım Prosedürleri: İnsan kaynakları yönetimi stratejisi, "Örgüt çevresindeki değişmelere göre ileride meydana gelecek ihtiyaçlarını öngörerek talep edilebilecek özelliklere sahip insan kaynağını geliştirmeye yönelik planlar, programlar ve eğilimler bütünü” şeklinde tanımlanmıştır (Özgeldi, 2002'den aktaran Deniz ve Ünal, 2007, s. 103-104).

Nihai hedefi kâr elde etmek olan ticari bir işletme olarak bankalarda, insan kaynakları stratejileri, bankanın yöneldiği genel strateji ile uyumlu olmalıdır. Teknoloji alt yapısını geliştirip alternatif dağıtım kanallarına müşterileri yönlendirmeyi ve bu yolla maliyetlerini azaltıp kâr elde etmeyi hedefleyen bir bankanın, şüphesiz, şube ağını genişletmesi ve şubelerde fazladan çalışan istihdam etmesi yanlış olacaktır. Bu nedenle, ilk olarak bankanın genel stratejisine göre insan kaynağının planlanması önem arz etmektedir.

İnsan kaynakları planlamasından sonra önemli olan husus, işlerin analizi, iş tanımları ve iş özelliklerinin belirlenmesidir. İş analizi kısmında, bir işin görev ve beceri gereksinimlerini ve bu iş için işe alınması gereken kişi türünü belirleme prosedürü gerçekleştirilmektedir. İş tanımları adı verilen aşama, işin görev, sorumluluk, raporlama ilişkileri, çalışma koşulları ve denetim sorumluluklarının listesi olarak ifade edilmektedir. İş özelliklerinin belirlenmesi kısmında ise, işin "insan gereksinimlerinin" yani zorunlu eğitim, beceri, kişilik yapısı gibi konulara karar verilmesi hedeflenmektedir (Dessler, 2020, s. 100). İş özelliklerinin belirlenmesi tamamlandıktan sonra, işe uygun çalışan özelliklerinin belirlenmesi ve çalışan alımı konuları gündeme gelmektedir.

Çalışan alımı söz konusu olduğunda, birçok bankanın yaklaşımı ilk olarak iç kaynaklara (halihazırda çalışan personeline) başvurmaktır (HSBC, YKB, QNB-Finansbank, Ziraat Bankası). Analizi gerçekleştirilmiş olan işe, uygun olduğunu düşünen çalışanların başvuru yapabilmesi için, ilgili pozisyonlar banka içi çeşitli platformlarda ilân edilmektedir. Böylece örgüt, terfi ya da tayin beklentisi olan çalışanların taleplerinin bir kısmını bu şekilde karşılamaktadır. İç kaynaklardan sonuç alınamadığı takdirde, bankalar dış kaynaklara başvurmaktadır. Çeşitli yöntemlerle pozisyonla alakalı ilanlar verilmekte ve toplanan başvurular arasında işe en uygun olanlar görüşmeye çağırılarak, adayların nitelikleri ve kişisel özellikleri dikkate alınarak, kimi zaman yazılı, kimi zaman sözlü, kimi zaman ise her iki yöntem uygulanarak çalışan seçimi gerçekleşmektedir.

İşe seçilen adaylar, ilk olarak oryantasyon programına tabi tutulmaktadır. Çalışanın kişisel özellikleri, nitelikleri, işin gerektirdiği özellikler göz önünde bulundurularak, çalışanlar, çeşitli eğitimler ve kişisel gelişim etkinliklerine tabi tutulmaktadır. Sadece ilk işe girişte değil, çalışanlar çalıştığı süre boyunca örgüt içi ve örgüt dışı olmak üzere, yetkinliklerini geliştirmeleri amacıyla eğitim programlarına tabi 
tutulmaktadır. Çalışanların becerilerinin geliştirilmesi, tutum ve davranışlarının değiştirilmesi, fikirlerin oluşturulması sürecinde ve örgütlerin yeniden yapılandırılma çalışmalarının tamamı eğitim ile mümkündür (Cantekinler, 2007, s. 47-51).

\section{Bankalarda Dijital (Elektronik) Bankacılık Uygulamaları}

Dünyada ve Türkiye'de bankacılığın şube dışına taşınmasında etkili olan teknolojik ilk yenilik sayılan ATM'ler (otomatik vezne makinesi), zaman geçse de, 7/24 para çekebilme olanağı tanıdığı ve sürekli yenileri ilave edilen bankacılık hizmetlerini karşılayabildiğinden, ortaya çıkışından bu yana işlerliğini devam ettirmiştir. Bir banka şubesinin yapabildiği işlemlerin neredeyse tamamını gerçekleştirebildiğinden kullanımlarının uzun zaman daha devam edeceği (belki de tamamen nakitsiz bir dünya düzenine ulaş1lıncaya kadar) düşünülmektedir.

Otomatik vezne makineleri (ATM) yanında, banka kartları, telefon bankacılığı, internet bankacıllğı, mobil bankacılık uygulamaları, mobil ödemeler ve teknolojinin etkisi ile her geçen gün çeşitlenen geniş bir ürün yelpazesinin ortaya çıkması ile dijital bankacılık teknolojileri yıllar içinde artmıştır. Hem yerel hem de küresel firsatlar yaratmak için dijital çağın altyapısını kullanma konusunda büyük firsatları gören bankalar, rekabetteki artış ve sektördeki diğer çeşitli zorluklar, kendilerine benzersiz kazanç kaynakları sunan yeni dijital modelleri hızla benimsemeye başlamıştır (Sardana ve Singhania, 2018, s. 28).

Otomatik Vezne Makinesi (ATM): Bilgisayarlar 1950'lerin ortasında Japon endüstrisine tanıtılmış ve bilgisayarlaşma hızla ilerlemiştir. Japonya'nın finans kurumları ise 1954'te bilgisayarlaşmaya başlamış̧ır. Otomatik para yatırma makineleri (AD'ler), nakit verme makineleri (CD'ler) ve son kullanıcilar olarak genel halkın vezne pencerelerine gerek duymadan paralarını yatırabileceği, çekebileceği veya aktarabileceği otomatik para çekme makineleri (ATM'ler) ortaya çıkmıştır. Günümüzde tüm dünyada nakit işlerini ve çok çeşitli müşteri hizmetlerini geliştirmek için araçlar olarak yaygın şekilde kullanılmaktadır (Hatta ve Liyama, 1991, s. 295-296). Diğer şube dışı bankacılık uygulamalarından en büyük farkı, zaman kısıtı olmaksızın para yatırma ve çekme işlemlerinin şube dışında gerçekleştirilebilmesidir.

Türkiye'nin en büyük özel bankası olan Türkiye İş Bankası, 1987 yılında Türk tüketicisine otomatik vezne makinelerini (ATM) tanıtarak Türkiye'de elektronik bankacılı̆̆ın temelini atmış ve 1998 yılı itibariyle ülkedeki ATM sayısı 7.400'ü aşmıştır (Polatoğlu ve Ekin, 2001, s. 156). Günümüzde ise Türkiye'de faaliyette bulunan ATM sayısı 31/12/2019 itibari le 46.749'dur (Türkiye Bankalar Birliği [TBB], 2020). Bankacılık hizmetlerinin artarak ilave edilebildiği bilgisayar alt yapısı sayesinde geçerliliğini sürdürmesi olasıdır. ATM'lerin kullanımı için ortaya çıkarılmış ATM kartları (debit kart), aynı esnada banka ve ATM harici işyerlerinde kullanıma olanak sağlayan üye işyerlerinde kredi kartlarının da ortaya çıkmasıyla yoğun olarak nakit taşıma gereksinimi olmaksızın kullanıma elverişli hale gelmiştir.

Telefon Bankacılı̆̆ı: Şube veya ATM bankacıllı̆ına kıyasla, telefon bankacılığının daha uygun maliyetli olduğu bilinmektedir. Bunun yanı sıra kolaylık, erişilebilirlik ve kazanılan zaman gibi unsurlar birçok müşterinin telefon bankacılığını tercih etmesinin sebeplerinden bazılarıdır (Sundarraj ve $\mathrm{Wu}, 2005$, s. 429). Zamandan bağımsız olarak bazı bankacılık işlemlerin anlık gerçekleşmesine, bazılarının ise işlem emirlerinin alınmasına ve ilk mesai saati başlangıcında işleme alınmasına olanak tanımaktadır. Dünya'da telefon bankacıllğı yirmi yılı aşkın süredir sürekli olarak ve kullanışlı bir özellik haline gelmiş ve tüm bankalar bu özelliği hizmetlerinin bir parçası olarak vermeye başlamıştır (Alikhani, Azad, Mousavi ve Mahmoudzadeh, 2013, s. 2737).

1997 yılının sonlarında, telefon bankacılığı hizmeti, müşterilerin nakit çekme dışındaki tüm işlemlerini yapmalarına izin verdiği için Türk müşteriler arasında da popüler hale gelmiştir (Polatoğlu ve Ekin, 2001, s. 157). Bankalar açısından şube açma maliyetlerinin ortadan kalkması, onay prosedürlerinin müşterinin kendisine tanımlanmış olan şifreler aracılığıyla tamamlanabilmesi gibi faydaları bulunmakta iken, müşteri için ise, şubeye ulaşma, şubede sıra bekleme, şubeden yapılan işlemler için alınan yüksek tutarlı işlem ücretlerini bertaraf etmek için cazip hale gelmektedir. Telefon bankacılığı, internet bankacılığı ve mobil bankacılık gibi kullanımı genellikle daha genç yaş grubu tarafından tercih edilen 
uygulamaların aksine bir çalışan yardımıyla işlemlerin gerçekleştirilmesi nedeniyle daha büyük yaş grupları tarafindan tercih edilebilmektedir.

Internet Bankacılı̆̆ı: İnternet bankacılığının ilk hali olarak ifade edilen bilgisayar bankacıllı̆ında, tüketiciler doğrudan bankanın bilgisayarıyla kablolu bir bağlantı kullanarak para transferi yapmak, faturalarını ödemek, hesap bakiyelerini kontrol etmek, hesap ekstrelerini incelemek ve çek siparişi vermek ve ödemeyi durdurma emri vermek gibi diğer bankacilık işlerini yürütmek için banka hesaplarına erişebilmekteydi (Anguelov, Hilgert ve Hogarth, 2004, s. 3). Ardından açık ağ alt yapısını kullanan internet bankacılığı, bankacılığın şubeden çıkıp kişilerin bulundukları lokasyonlarda kendi kendilerine bankacılık işlemlerini yapmasına olanak tanıyan ve aynı anda birçok kişinin hizmetten yaralanmasını sağlayan bir yapıya dönüşmüştür. Dolayısıyla, kişilerin bir banka şubesi, ATM ya da telefon bankacılığına gerek duymadan, internet bağlantısı ve bir bilgisayar yardımıyla işlemlerin kendi kendilerine gerçekleştirilmesine olanak sağlamaktadır.

Dünyada ilk "Security First Network Bank (SFNB)", 1995 yılında güvenli çevrimiçi bağlantılı olarak faaliyet göstermeye başlamıştır (Lin, Wang ve Hung, 2020, s. 3). Türkiye'de ise internet bankacılığını ilk olarak 1997 yılı Haziran ayında Türkiye İş Bankası faaliyete geçirmiş ve takiben Temmuz 1997'de Garanti Bankası müşterilerine internet hizmetini sunmaya başlamıştır (Uzundağ, 2013, s. 36). O günden bu yana giderek artan bir şekilde kullanılmaktadır. İlk zamanlar, havale, EFT, virman gibi para transfer işlemleri gerçekleştirilebilirken, günümüzde, döviz, altın, hisse senedi gibi yatırım ürünlerinin alımsatımı, fatura tahsilatları, cep telefonu görüşme bedeli yükleme, ceza ödeme, öğrenci harçlarının ödenmesi, e-devlet uygulamalarına şifresiz giriş, kredi başvurusu ve kullanımı işlemleri gibi birçok farklı işlemin gerçekleştirilmesine olanak tanımaktadır.

Mobil Bankacılık: Mobil bankacılık, bir dizi yeni mobil teknoloji harikasının şimdilik en sonuncusudur. Otomatik vezne makinesi (ATM), telefon ve internet bankacıllğı geleneksel bankacılık ürünleri için etkili dağıtım kanalları sunsa da, birçok gelişmiş ve gelişmekte olan ülkede perakende ve mikro-finans bankaları tarafindan kurulan en yeni dağıtım kanalı olarak, mobil bankacılığın önemli etkileri bulunmaktadır (Safeena, Date, Kammani ve Hundewale, 2012, s. 1021).

İnternet bankacılığının zamandan bağımsız işlem yapabilme yeteneğinin yanında, mobil bankacılıkta mekândan bağımsızlık da söz konusudur. Kablosuz ă̆ bağlantılarını kullanarak, kablosuz cihazlar yardımıyla işlemler her an, her yerden gerçekleştirilebilmektedir. Bankaların sağlamış oldukları, internet tabanlı ve mobil cihazlara indirilebilen uygulamalar sayesinde, çeşitli yöntemler kullanılarak (göz okuma, parmak izi okuma, çizilebilen şifreler gibi) sisteme giriş yapılan ve tıpkı internet bankacılığındaki gibi birçok farklı bankacılık işleminin gerçekleştirilmesi mümkün hale gelmiştir. $\mathrm{Bu}$ hizmet aynı zamanda bir takım ticari ilişkilerin güvenli şekilde yürütülmesi amacıyla da kullanılmaktadır (Aytar, Yeğen ve Erdemir, 2012, s. 6).

Dijital bankacılık uygulamaları ilk etapta yüklü bir teknoloji yatırımı gerektirmesinin yanında, uzun vadede şube açma maliyetleri, açılan şubede çalışan istihdam edilmesi, şubede gerçekleştirilen işlem başına basılması gerekli olan dekont maliyetine kadar bir çok kalemde tasarruf etmesine sebep olmaktadır. Yapılacak yatırımın fiziki olarak şubelere yapılması yerine bilgi teknolojileri alt yapısına yönlendirilmesi mümkün hale gelmektedir. İlaveten, piyasadaki değişen rekabet koşulları ve yoğunlaşan rekabet ortamı içinde, etkin bir şekilde çalışmayı başaranlar hayatta kalmaya devam edecek, başaramayanlar ise, yok olma tehlikesiyle karşı karşıya kalacaktır (Aytar, Yeğen ve Erdemir, 2012, s. 4).

\section{Gri Tahmin Yöntemlerinden GM(1,1) Modeli}

Gri sistem teorisi, ilk olarak 1980'lerin başında Deng (1982) tarafindan ortaya atılan disiplinler arası bir bilimsel alandır. O zamandan beri teori, kısmen bilinmeyen parametrelere sahip sistemlerle başa çıkma yeteneği ile oldukça popüler hale gelmiştir. Geleneksel istatistiksel modellere üstünlük olarak, gri modeller, bilinmeyen sistemlerin davranışını tahmin etmek için yalnızca sınırlı miktarda veriye ihtiyaç duymaktadır (Deng, 1989'dan aktaran Kayacan, Ulutaş ve Kaynak, 2010, s. 1784). Gri sistem gri sayılar ile tanımlanabilmektedir. Gri sayı, değeri kesin olarak bilinmeyen fakat alabileceği değerler için sınırları bilinen sayılara verilen isimdir. Gri sistemler, bilinen bilgi miktarına göre adlandırılır. Tam bilgiye sahip sistemler beyaz, tam olarak bilinmeyen bilgiye sahip sistemler siyah, kısmi bilgiye sahip sistemler gri 
renk ile temsil edilir (Lin, Chen ve Liu, 2004, s. 197). Gri Tahmin yöntemlerinden GM(1,1) modeli, tek değişkene sahip birinci dereceden türevlenebilir eşitliklerin yer aldığı gri modeli tanımlamak için kullanılmaktadır (Liu ve Lin, 2010, s. 107).

GM(1,1) modeli yedi aşamadan oluşmaktadır (Liu ve Lin, 2010, s. 107-108):

Așama 1: Aşağıdaki gibi ham bir veri seti oluşturulur. $X^{(1)}=\left(x^{(1)}(1), x^{(1)}(2), x^{(1)}(3), \ldots, x^{(1)}(n)\right)$ ile birikim oluşturduğu dizi belirtilir.

$\mathrm{X}^{(0)}=\left(\mathrm{x}^{(0)}(1), \mathrm{x}^{(0)}(2), \mathrm{x}^{(0)}(3), \ldots, \mathrm{x}^{(0)}(\mathrm{n})\right)$

Aşama 2: Ardından $\mathrm{X}^{(0)} \mathrm{k}+\mathrm{ax}^{(1)}(\mathrm{k})=\mathrm{b} \mathrm{GM}(1,1)$ modelinin orijinal formu olarak anılır, burada $\mathrm{GM}(1,1)$ sembolü "tek değişkende birinci dereceden gri modeli" temsil eder.

$\mathrm{X}^{(1)}=\left(\mathrm{x}^{(1)}(1), \mathrm{X}^{(1)}(2), \mathrm{x}^{(1)}(3), \ldots, \mathrm{x}^{(1)}(\mathrm{n})\right)$

$\mathrm{X}^{(0)} \mathrm{k}+\mathrm{ax}^{(1)}(\mathrm{k})=\mathrm{b}$

Aşama 3: $\mathrm{Z}^{(1)}(\mathrm{k})$ bitişik komşu araçlarla $\mathrm{X}^{(1)}$, den üretilen dizi olsun.

Yani; $\mathrm{Z}^{(1)}(\mathrm{k})=1 / 2\left(\mathrm{x}^{(1)}(\mathrm{k})+\mathrm{x}^{(1)}+(\mathrm{k}-1)\right), \mathrm{k}=2,3, \ldots, \mathrm{n}$.

$\mathrm{X}^{(0)} \mathrm{k}+\mathrm{az}(1)(\mathrm{k})=\mathrm{b}$ GM$(1,1)$ modelinin temel formu olarak anılır.

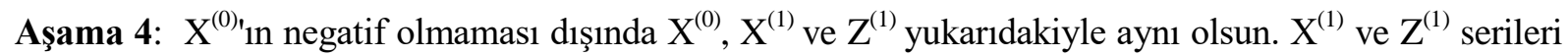
oluştuktan sonra $\hat{a}=(a, b)^{\mathrm{T}}$ parametrelerinin bir dizilimi ise,

$\mathrm{Y}=\left[\begin{array}{c}\mathrm{x}^{(0)}(2) \\ \mathrm{x}^{(0)}(3) \\ \vdots \\ \mathrm{X}^{(0)}(\mathrm{n})\end{array}\right], \mathrm{B}=\left[\begin{array}{cc}-\mathrm{z}^{(1)}(2) & 1 \\ -\mathrm{z}^{(1)}(3) & 1 \\ \vdots & \vdots \\ -\mathrm{Z}^{(1)}(\mathrm{n}) & 1\end{array}\right]$

En küçük kareler yöntemiyle tahminlenirse, $\mathrm{x}^{(0)} \mathrm{k}+\mathrm{az}^{(1)}(\mathrm{k})=\mathrm{b}$ eşitliğinin kullanılmasıyla $\mathrm{GM}(1,1)$ modelinin parametrelerini gösteren â vektörü hesaplanır. $\hat{a}=(a, b)^{\mathrm{T}}$ şu şekilde hesaplanmaktadır:

$\hat{\mathrm{a}}=\left(\mathrm{B}^{\mathrm{T}} \mathrm{B}\right)^{-1} \mathrm{~B}^{\mathrm{T}} \mathrm{Y}$

Aşama 5: Eğer,

$\hat{\mathrm{a}}=\left(\mathrm{B}^{\mathrm{T}} \mathrm{B}\right)^{-1} \mathrm{~B}^{\mathrm{T}} \mathrm{Y}$ ise;

$\frac{\mathrm{dx}^{(1)}}{\mathrm{dt}}+\mathrm{ax}^{(1)}=\mathrm{b}$, şeklinde gösterilen birinci dereceden türevi alınabilen eşitlik elde edilir;

$\mathrm{x}^{(1)} \mathrm{t}=\left(\mathrm{x}^{(1)}(1)-\frac{\mathrm{b}}{\mathrm{a}}\right) \mathrm{e}^{-\mathrm{at}}+\frac{\mathrm{b}}{\mathrm{a}}$ ile gösterilir. Yani, $\hat{\mathrm{x}}^{(1)}(\mathrm{k}+1)=\left(\mathrm{x}^{(1)}(1)-\frac{\mathrm{b}}{\mathrm{a}}\right) \mathrm{e}^{-\mathrm{ak}}+\frac{\mathrm{b}}{\mathrm{a}}$,

$\mathrm{k}=1,2,3, \ldots, \mathrm{n}$.

Aşama 6: Daha sonra elde edilmiş olan birinci dereceden türevi alınabilir eşitliğe ters kümülatif işlemi uygulanır ve tahmin edilen değerler aşağıda bulunan model ile elde edilir.

$\hat{\mathrm{x}}^{(0)}(\mathrm{k}+1)=\mathrm{a}^{(1)} \hat{\mathrm{x}}(\mathrm{k}+1)=\hat{\mathrm{x}}^{(1)}(\mathrm{k}+1)-\hat{\mathrm{x}}^{(1)}(\mathrm{k})=\left(1-\mathrm{e}^{\mathrm{a}}\right)\left(\mathrm{x}^{(0)}(1)-\frac{\mathrm{b}}{\mathrm{a}}\right) \mathrm{e}^{-\mathrm{ak}}$,

$\mathrm{k}=1,2,3, \ldots, \mathrm{n}$.

Aşama 7: Ardından üretilen tahmin değerlerinin hata payı hesaplanır ve modelin gelecek dönem değerlerini tahmin için kullanılıp kullanılamayacağı test edilir. $\mathrm{X}^{(0)}$ ham veri setinin herhangi bir $\mathbf{k}$ değeri için tahmin hatası $\varepsilon^{(0)}(\mathrm{k})$ ile gösterilir. Şu şekilde hesaplanır;

$\varepsilon^{(0)}=(\varepsilon(1), \varepsilon(2), \ldots, \varepsilon(\mathrm{n}))=\left(\mathrm{x}^{(0)}(1)-\hat{\mathrm{x}}(1), \mathrm{x}^{(0)}(2)-\hat{\mathrm{x}}(2), \ldots, \mathrm{x}^{(0)}(\mathrm{n})-\hat{\mathrm{x}}(\mathrm{n})\right)$

$\mathrm{X}^{(0)}$ ham veri setinin herhangi bir $\mathrm{k}$ elemanı için hata oranı ise, $\Delta_{\mathrm{k}}$ olarak belirtilir. 
Aşağıdaki şekilde hesaplanıp, yüzdesi alınarak ifade edilir.

$\Delta_{\mathrm{k}}=\left(\left|\frac{\varepsilon(1)}{\mathrm{X}^{(0)}(1)}\right|,\left|\frac{\varepsilon(2)}{\mathrm{X}^{(0)}(2)}\right|, \ldots,\left|\frac{\varepsilon(\mathrm{n})}{\mathrm{X}^{(0)}(\mathrm{n})}\right|\right)=\left\{\Delta_{\mathrm{k}}\right\}_{1}^{\mathrm{n}}$

Ortalama göreli hata ise eşitlik 12 ile hesaplanır.

$\bar{\Delta}=\frac{1}{2} \sum_{\mathrm{k}=1}^{\mathrm{n}} \Delta_{\mathrm{k}}$

$\mathrm{Bu}$ hesaplama sonrasında modelin test doğruluk ölçeğine göre kontrol edilir. Eğer; $\bar{\Delta}<\alpha$ ise gelecek tahmini yapılabilir. $1-\bar{\Delta}$ ise, modelin güvenirlik oranını verir.

\section{BULGULAR}

Bu çalışmada, Türkiye'de faaliyet gösteren bankalara ait bazı değişkenlerinin (toplam banka sayısı, toplam şube sayısı, toplam ATM sayıları, bankaların çă̆rı merkezleri aracıll̆ğıla almış oldukları toplam müşteri çağrllarl, toplam aktif internet bankacılığı ve toplam aktif mobil bankacılık kullanıcı sayılarını) geçmiş yıllara ait verileri kullanılarak gelecek y1llara/dönemlere ait tahmini değerlerinin belirlenmesi amaçlanmaktadır. Amaç doğrultusunda, TBB internet sitesinden temin edilmiş olan 20112017 yılları arasındaki, toplam banka sayısı, toplam şube sayısı, toplam ATM sayısı, bankaların çağn merkezleri aracılığıyla alınan toplam müşteri çağrı sayısı, toplam aktif internet bankacılığı ve toplam aktif mobil bankacılık kullanıcı sayısı çalışmanın veri setini oluşturmaktadır (Türkiye Bankalar Birliği [TBB], 2020). Bahsi geçen verilerin, Gri Tahmin yöntemlerinden GM(1,1) Metodu kullanılarak, 20192023 yılları arasındaki değerleri tahmin edilmiştir. Çalışmanın önemi, neredeyse 190.000 çalışana sahip bir sektör olması nedeniyle, kariyerine devam eden ya da bu sektörde kariyer edinmek isteyen kişiler için bir öngörü çalışması olmasıdır. Ayrıca, ilgili literatürde Gri Tahmin ile dijital bankacılık uygulamalarının tahmini arasında bir çalışmaya rastlanılmamıştır. Bu yöntemle, banka kârlılıkları (Ömürbek, Aksoy, Akçakanat, 2018; Ömürbek, Akçakanat, Aksoy, 2018), maliyet tahmini (Özer Keçe, Ömürbek, Acar, 2016), kredi kartı kullanımı (Yıldırım, Keskintürk, 2015), bankalardaki bireysel kredi risklerinin tahmini (Aksoy ve Akçakanat, 2019), tekstil moda renk tercih trendi (Lin vd., 2010), sığır eti tüketimi (Zeng, Li, Meng ve Zhang, 2019), bilimsel yayınların tahmini (Aydemir, Bedir ve Özdemir, 2013), basınç verileri (Kaleli, Ceviz ve Erentürk, 2014), deformasyon tahmini (Taşç1, 2017), doğalgaz talep tahmini (Oruç ve Çelik Eroğlu, 2017; Wang, Liu ve Yang, 2018; Lu, 2018), ekonomik büyüme tahmini (Önalan ve Başeğmez, 2018), elektrik üretim ve tüketim tahmini (Zhao ve Zhou, 2018; Şahin, 2018; Es, 2020), sağllk sektörü harcamaları ( Öztürk ve Bilgil, 2019), sağllk sektörüne talep tahminleri (Zor ve Çebi, 2018; Şahin, 2019; Oruç ve Başağaoğlu Fındık, 2020), kripto para fiyatları tahmini (Şahin ve Bağcı, 2020), inşaat endüstrisi tedarik zinciri tahmini (Nguyen ve Tran, 2018; Nguyen, 2020), turist sayıları tahmini (Javed, Ikram, Tao ve Liu, 2020), kalite yönetm sistemlerinin geleceği (Ikram, Zang ve Sroufe, 2020), uçak endüstrisi tahmini (Carmona-Benitez ve Nieto, 2020), otomobil endüstrisi talebi (Tran, 2018) gibi farklı disiplinlere ait konular üzerinde tahminlemeler yapıldığı görülmüsstür. Gri Tahmin yöntemlerinden birisi olan $\operatorname{GM}(1,1)$ Modeli kullanılarak bankalara ait bazı değişkenlerinin tahminlenmesi bu çalışmanın özgün tarafına vurgu yapmaktadır.

Çalışma kapsamında TBB (2020)'den Türk bankacılık sisteminde faaliyet gösteren tüm bankalara ait veriler elde edilerek, toplam banka sayısı, toplam şube sayısı, çalışan sayısı, ATM, Telefon bankacılığı gelen çağrı sayısı, internet bankacılığı kullanıcı sayısı ve mobil bankacılık kullanıcı sayısı verilerine ait korelasyon, ortalama ve standart sapma değerleri hesaplanmıştır. İlgili hesaplamalar Tablo 1'de gösterilmiştir.

Tablo 1. Değişkenler Arasındaki Korelasyon, Ortalama ve Standart Sapma Değerleri

\begin{tabular}{|c|c|c|c|c|c|c|c|} 
Değişkenler & IBBKS & MBKS & TBGÇS & BS & ŞS & ATMS & ÇS \\
\hline İBKS & 1 & & & & & & \\
\hline MBKS & $-0,103^{* * * *}$ & 1 & & & & & \\
\hline TBGÇS & $0,419^{* * *}$ & $0,760^{* * *}$ & 1 & & & & \\
\hline BS & $0,494^{* * *}$ & $0,621^{* * *}$ & $0,896^{* * *}$ & 1 & & & \\
\hline ŞS & $0,534^{* * *}$ & $-0,565^{* * *}$ & $-0,093^{* * *}$ & $0,109^{* * *}$ & 1 & & \\
\hline
\end{tabular}

IBAD Sosyal Bilimler Dergisi / IBAD Journal of Social Sciences, (Özel Say1/Special Issue), 2020 


\begin{tabular}{c|c|c|c|c|c|c|c} 
Değiş̧kenler & İBKS & MBKS & \multicolumn{1}{c}{ TBGÇS } & BS & \multicolumn{1}{c}{ ŞS } & ATMS & ÇS \\
\hline ATMS & $0,344^{* * *}$ & $0,827^{* * *}$ & $0,949^{* * *}$ & $0,891^{* * *}$ & $-0,050^{* * *}$ & 1 & \\
\hline ÇS & $0,635^{* * *}$ & $-0,371^{* * *}$ & $0,148^{* * *}$ & $0,322^{* * *}$ & $0,969^{* * *}$ & $0,189^{* * *}$ & 1 \\
\hline Ort. & $14.096 .980,75$ & $20.133 .489,13$ & $108.430 .620,00$ & 46,50 & $10.700,63$ & $42.654,0$ & $194.625,8$ \\
\hline Std. Sp. & $3.250 .249,012$ & $17.716 .839,145$ & $16.501 .856,296$ & 0,926 & 413,150 & $4.722,64$ & $5.446,837$ \\
\hline
\end{tabular}

Kodlama: İnternet Bankacılığı Kullanıcı Sayısı: IBKSS; Mobil Bankacılı̆̆ı Kullanıcı Sayısı: MBKS; Telefon Bankacıllı̆ı Gelen Çağrı Sayısı: TBGÇS; Banka Sayısı: BS; Şube Sayısı: ŞS; ATM Sayısı: ATMS; Çalışan Sayısı: ÇS

Korelasyon analizi sonucu elde edilen değer ilişki düzeyini (r) göstermektedir (bkz. Ural ve Kıllıç, 2013, s. 244). Değişkenlere ait tahmini değerlerin hesaplanmasından önce değişkenler arasında çoklu doğrusallık sorunu (değişkenler arası korelasyon değerinin 0.85 'in üstünde olması) olup olmadığının incelenmesi için korelasyon analizi yapılmıştır (Gürbüz, 2019, s. 42). Elde edilen sonuçlara göre değişkenler arasında bir çoklu doğrulsallık sorunu tespit edilmemiştir. Uygulamanın ikinci aşaması olan değişkenlerin tahminlemesine geçilmiştir. Tahminen 7 farklı değişken olduğu için örnek olarak "banka sayısı" değişkeninin tahminlemesi aşamalar üzerinde gösterilmiş olup diğer değişkenlerde de bu aşamalar uygulanmıştır. Banka sayısının $\mathrm{GM}(1,1)$ göre tahminlenmesi için gerekli aşamalar aşağıda maddeler halinde gösterilmektedir. Bunlar:

Aşama 1: Eşitlik (1) kullanılarak aşağıdaki denklem elde edilmektedir.

$\mathrm{X}^{(0)}=(45,0 ; 45,0 ; 47,0 ; 47,0 ; 47,0 ; 47,0)$

Aşama 2: Eşitlik (2) kullanılarak aşağıdaki denklem elde edilmektedir.

$\mathrm{X}^{(1)}=(45,0 ; 90,0 ; 137,0 ; 184,0 ; 231,0 ; 278,0)$

Verilerin tahminlemeye uygunluğu için yarı düzgünlük ve yarı üssellik değerlerinin belirlenmesi gerekmektedir. Yarı düzgünlük değerleri aşağıda gösterilmektedir.

a) $p(5)=\frac{x_{(5)}^{(0)}}{x_{(4)}^{(1)}}=\frac{47,0}{184,0}=0,25543$

b) $p(6)=\frac{x_{(6)}^{(0)}}{x_{(5)}^{(1)}}=\frac{47,0}{231,0}=0,20346$

Yarı üssellik değerleri aşağıda gösterilmektedir.

a) $\sigma^{(1)}(5)=\frac{x_{(5)}^{(1)}}{x_{(4)}^{(1)}}=\frac{231,0}{184,0}=1,25543$

b) $\sigma^{(1)}(6)=\frac{x_{(6)}^{(1)}}{x_{(5)}^{(1)}}=\frac{278,0}{231,0}=1,20346$

Aşama 3: Eşitlik (4) kullanılarak aşağıdaki denklem elde edilmektedir.

$\mathrm{Z}^{(1)}=(45,0 ; 67,5 ; 113,5 ; 160,5 ; 207,5 ; 254,5)$

Aşama 4: Eşitlik (6) kullanılarak aşağıdaki matris elde edilmektedir.

$\mathrm{Y}=\left[\begin{array}{l}45,0 \\ 47,0 \\ 47,0 \\ 47,0 \\ 47,0\end{array}\right] ; B=\left[\begin{array}{cc}67,5 & 1 \\ 113,5 & 1 \\ 160,5 & 1 \\ 207,5 & 1 \\ 254,5 & 1\end{array}\right]$

Eşitlik (7) kullanılarak aşağıdaki denklem elde edilmektedir. 
$\hat{\mathrm{a}}=\left(\mathrm{B}^{\mathrm{T}} \mathrm{B}\right)^{-1} \mathrm{~B}^{\mathrm{T}} \mathrm{Y}=\left[\begin{array}{c}-0,00851 \\ 45,23239\end{array}\right]$

Aşama 5: Eşitlik (8) kullanılarak aşağıdaki denklem elde edilmektedir.

$\frac{\mathrm{dx}^{(1)}}{\mathrm{dt}}-0,00851 \mathrm{x}^{(1)}=45,23239$

$\hat{\mathrm{x}}^{(1)}(\mathrm{k}+1)=\left(\mathrm{x}^{(1)}(1)-\frac{\mathrm{b}}{\mathrm{a}}\right) \mathrm{e}^{-\mathrm{ak}}+\frac{\mathrm{b}}{\mathrm{a}}=5360,00000 \mathrm{e}^{-0,00851 \mathrm{k}}-5315,00000$

$\mathrm{x}^{(1)}=(90,8 ; 137,0 ; 183,6 ; 230,6 ; 278,0)$

Aşama 6: Eşitlik (9), (10) ve (11) kullanılarak aşağıdaki denklem elde edilmektedir.

$\mathrm{x}^{(0)}=(45,8 ; 46,2 ; 46,6 ; 47,0 ; 47,4)$

Tablo 2. Banka Sayısı İçin Kurulan Modelin Hata Payı ve Göreli Hata Oranının Hesaplanması

\begin{tabular}{|c|c|c|c|c|}
\hline & Ham Veri & Tahmini Veri & Hatalar & Göreli Hatalar \\
\hline Yillar & $\mathrm{x}^{(0)} \mathrm{k}$ & $\hat{\mathrm{X}}^{(0)} \mathrm{k}$ & $\varepsilon(\mathrm{k})=\mathrm{x}^{(0)} \mathrm{k}-\hat{\mathrm{x}}^{(0)} \mathrm{k}$ & $\Delta_{\mathrm{k}}=|\varepsilon(\mathrm{k})| / \mathrm{x}^{(0)}(\mathrm{k})$ \\
\hline 2012 & 45,0 & 45,0 & 0,00000 & 0,00000 \\
\hline 2013 & 45,0 & 45,8 & $-0,81001$ & 0,01800 \\
\hline 2014 & 47,0 & 46,2 & 0,79847 & 0,01699 \\
\hline 2015 & 47,0 & 46,6 & 0,40360 & 0,00859 \\
\hline 2016 & 47,0 & 47,0 & 0,00536 & 0,00011 \\
\hline 2017 & 47,0 & 47,4 & $-0,39629$ & 0,00843 \\
\hline
\end{tabular}

Aşama 7: Eşitlik (12) kullanılarak aşağıdaki ortalama göreli hata değeri elde edilmektedir.

$\bar{\Delta}=\% 1,04244$

Bu değerin çok düşük bir düzeyde olduğu ve banka sayısıyla ilgili gelecek tahmini değerlerinin \%98,96 oranında bir güvenirlikle tahmin edildiği görülmektedir.

Tablo 3. Banka Sayısı İçin Gelecek Dönemler için Tahmin Değerleri

\begin{tabular}{|c|c|c}
\hline Yıllar & Tahmini Banka Sayısı & Tahmini Banka Sayısı ( $\approx)$ \\
\hline $\mathbf{2 0 1 8}$ & 47,8 & 48 \\
\hline $\mathbf{2 0 1 9}$ & 48,2 & 48 \\
\hline $\mathbf{2 0 2 0}$ & 48,6 & 49 \\
\hline $\mathbf{2 0 2 1}$ & 49,0 & 49 \\
\hline $\mathbf{2 0 2 2}$ & 49,5 & 50 \\
\hline $\mathbf{2 0 2 3}$ & 49,9 & 50 \\
\hline
\end{tabular}

Türkiye'de faaliyet gösteren tüm bankaların sayısı önümüzdeki iki yıllık süreçte 2020 Haziran itibari ile TBB (2022)'nin ilan ettiği banka sayısı olan 48'den iki fazla yani 50 bankaya çıkması tahmin edilmiştir. Şube sayısı, çalışan sayısı, ATM Sayısı, internet bankacılığı kullanıcı sayısı, mobil bankacılık kullanıcı sayısı ve telefon bankacılığı gelen çağrı sayısının hesaplanmış değerleri Tablo 4'de gösterilmiştir.

Tablo 4. Değişkenlerin Gelecek Yıllara ait Değerlerin Tahmini Sonuçları

\begin{tabular}{|c|c|c|c|c|c|c|}
\hline Değişkenler & $\mathbf{2 0 1 8}$ & $\mathbf{2 0 1 9}$ & $\mathbf{2 0 2 0}$ & $\mathbf{2 0 2 1}$ & $\mathbf{2 0 2 2}$ & $\mathbf{2 0 2 3}$ \\
\hline Şube Sayısı & 9.945 & 9.729 & 9.519 & 9.312 & 9.111 & 8.913 \\
\hline Çalışan Sayısı & 185.906 & 183.138 & 180.411 & 177.725 & 175.078 & 172.471 \\
\hline ATM Sayısı & 48.176 & 49.083 & 50.007 & 50.948 & 51.907 & 52.884 \\
\hline $\begin{array}{c}\text { Internet Bankacılı̆̆ı } \\
\text { Kullanıcı Sayısı }\end{array}$ & 10.289 .483 & 9.102 .495 & 8.052 .438 & 7.123 .515 & 6.301 .751 & 5.574 .786 \\
\hline Telefon Bankacılığı & 120.918 .790 & 121.353 .053 & 121.788 .876 & 122.226 .263 & 122.665 .222 & 123.105 .757 \\
\hline
\end{tabular}




\begin{tabular}{|c|c|c|c|c|c|c|}
\hline Değişkenler & 2018 & 2019 & 2020 & 2021 & 2022 & 2023 \\
\hline \multicolumn{7}{|l|}{ Gelen Çağrı Sayısı } \\
\hline Değişkenler & 2020 3Ç & 2020 4Ç & $20211 C ̧$ & $20212 C ̧$ & 2021 3Ç & 2021 4Ç \\
\hline $\begin{array}{l}\text { Mobil Bankacılık } \\
\text { Kullanıcı Sayısı }\end{array}$ & 61.529 .027 & 66.094 .716 & 70.999.197 & 76.267.609 & 81.926.957 & 88.006.251 \\
\hline
\end{tabular}

Türkiye'de faaliyet gösteren 2020 Haziran itibari ile 10.132 (gerçek değer) olan şube sayısının 2023 sonunda 8.913 (tahmini değer) şubeye kadar düşmesi tahmin edilmiştir. Şube sayısının düşme tahmini ile benzerlik gösteren banka çalışanlarının 2020 Haziran sonu itibariyle 187.490 olan sayısı 2023 sonunda 172.471 kişiye kadar düşmesi tahminlenmiştir. 2015 y1lından bu yana sektördeki bankacı sayısının sürekli azalıyor olması, yapılan tahmini destekler niteliktedir. 2010 yılından bu yana ATM sayıları, şube dışı bankacı1ık uygulaması olması nedeniyle sürekli artan bir seyir göstermektedir. $\mathrm{Bu}$ nedenle elde edilen altı yıllık tahminde bu artışın devam edeceği beklenmektedir. İnternet bankacılığ aktif kullanıcı sayısı 2016 yılından bu yana azalış göstermektedir. Dolayısıyla 2020-2023 arası hesaplanan tahmin değerleri bu trendin devam edeceği beklentisini oluşturmaktadır. Aktif olarak mobil bankacılık kullanan kullanıcı sayıları, paylaşılmaya başlandığı 2011 yılından bu yana sürekli artış göstermektedir. yıllık veriler (2012-2017 arası) ile tahminleme denenmiş olup, Gri Tahmin yöntemi olan GM(1,1) Modeline uygun olmadığı tespit edilmiştir. Bu nedenle, 2019-4 çeyrek ve 2020-2 çeyrek verileri olmak üzere toplamda 6 çeyrek verisi kullanılarak tahmin gerçekleştirilmiştir. Eski verileri destekler nitelikte altı çeyreklik tahmin artış trendini göstermektedir. Telefon bankacılığ gelen çağrı sayıları incelendiğinde, 2012-2017 yılları arasında az da olsa artışlar bulunmaktadır. Gerçekleştirilen 6 yıllık tahminde de artı̧s trendi söz konusudur.

\section{SONUÇ}

İnsan kaynakları stratejilerinin değişiklik gösteren yapısı, büyük ölçüde bankacılık sisteminin dijitalleşmesi ve teknolojik ürünler kullanılarak bankacılık işlemlerinin, müşterilerin kendileri tarafından zaman ve mekândan bağımsız olarak yapabilir hale gelmesine bağlıdır. Bu kapsam göz önünde bulundurularak yapılmış olan bu çalışmada ilk olarak, Türkiye'de faaliyet gösteren toplam banka sayısı, toplam şube sayısı, toplam çalışan sayısı gibi insan kaynağı ile ilgili veriler ile alternatif bankacılık kanalları olarak adlandırılan toplam ATM sayısı, internet bankacılığı aktif kullanıcı sayısı, mobil bankacılık aktif kullanıcı sayısı ve telefon bankacılığına gelen toplam çağrı sayısı arasındaki korelasyon, ortalama ve standart sapma değerleri hesaplanmıştır. Ardından veriler ile ilgili hazırlanmış olan, 7 farklı parametreye ait olan 6 dönemlik tahminler gerçekleştirilmiştir. Gri Tahmin yöntemi ile verilerin tahminlenmesi sonucunda, banka sayısı, ATM sayıs1, mobil bankacılık kullanıcı sayısı ve telefon bankacılı̆̆ gelen çağrı sayılarının artacağı tahmin edilirken, toplam şube sayısı, toplam çalışan sayısı ve internet bankacılığı kullanıcı sayılarının azalacağı tahmin edilmiştir. Banka sayısı artışı söz konusu olacak olsa bile, bunun toplam şube ve toplam çalışan sayısına artış yönünde bir değişime yol açmayacağı görülmektedir. Şube sayısının azalacağı tahmini ve buna bağlı olarak toplam banka çalışanı sayısının azalacağı tahmini de makul görülmektedir. Bankalar, geçmişte yeni şube açılmasına ve müşteriyle, müşterinin bulunduğu lokasyonda ve şube-müşteri etkileşimi içerisinde çalışmaya ağırlık vermiştir. Ancak günümüzde bu anlayış, şube açmanın yüksek maliyetli bir yatırım olması, alternatif dağıtım kanallarının büyük bir müşteri kesimi tarafından süreç içinde benimsenmiş olması, daha az personelle daha yüksek iş hacmi ve kârlılığının yakalanabilmesi gibi nedenlerle, yeni şube açmak bir yana, mevcut şubelerin kapanması sonucunu doğurmuştur. Hatta kurulu olan şubelerde minimum düzeyde personel çalsştırmanın bankalar tarafından tercih edileceği düşünülmektedir. Şube sayısı ve çalışan sayısı değişkenlerinin arasındaki korelasyon değerleri de bu ilişkiyi destekler niteliktedir.

ATM sayılarının artış tahmini ile ilgili olarak, bankacılığın kişiler tarafından günde güne artarak bankaya gitmeden yapılmaya başlanmış olması ile ilgili olduğu düşünülmektedir. Ayrıca bu artış, ATM'lerin yirmi yılı aşkın bir süredir ülkemizde şube harici nakit para çekme ve yatırma işlemlerinin yapıldığı tek yöntem olmasına bağlı olabilir. Yurttadur ve Süzen (2016), yaptıkları çalışmada kullanılan banka imkânlarının başında, internet bankacılığından sonra ATM geldiğini belirtmiştir. Müşterilerin banka kanalı tercihlerini araştıran çalışmalarda, genellikle ATM'lerin yaygın olması tercihi ön plana çıkmaktadır. Çalışmalarda ağırlıklı olarak anket yöntemi tercih edilmiştir (Yurttadur ve Bulut, 2015; 
Korkmaz, vd., 2015;Tepeli ve Daşkıran, 2019). Öte yandan internet bankacılığı kullanıcı sayıSı tahmininde bir azalma söz konusu iken, mobil bankacılık aktif kullanıcı sayısı tahminleri artmaktadır. Bu durumu, bilgisayarların sabit bir yerden hizmetlere ulaşım sağlamasına karşın, akıllı taşınabilir cihazlar yardımıyla kullanılan mobil bankacılık uygulamalarının, her yerden her zaman prensibi ile kullanılabilmesi açıklamaktadır. Elbette toplumdaki akıllı telefon kullanım alışkanlığının hızlı bir şekilde atış göstermesi ve akıllı telefonların çalışma prensibinin kablosuz ağ bağlantıları ile sağlanması gibi konular etkili olmuştur.

Toplam şube ve çalışan sayılarındaki azalma tahmini, ATM sayıları artış tahmini ve mobil bankacılık artış tahmini ile beraber düşünüldüğünde, (aralarındaki ilişkinin çok yüksek düzeyde ve aynı yönlü olduğunu göz önünde bulunduracak olursak) bankaların daha az maliyetli, daha az kişi çalıştırmaya ihtiyaç duyulan elektronik kanalları tercih edeceği açıktır. Ayrıca şube kârlılıkları ile ilgili yapılmış bir araştırmada Çilan ve Can (2013), bir şubede çalışan personel sayısı arttıkça kârlılığa olumlu etkisi olduğunu belirtmiștir. Ancak her ilave eleman, ilave yükümlülükler getireceğinden, bankalar artık minimum düzeyde çalışan istihdam etmek istemektedir. Ayrıca şubeler, ekonomik konjonktürden oldukça yakından etkilenmektedir. Arabacı (2018), bankacılık sektörünü incelediği çalışmasında kriz dönemlerinde bankaların şube sayılarında azalmaya gitmesinden bahsetmiştir. Çalışma, BDDK verileri dikkate alınarak, verilerin yorumlanması ile gerçekleştirilmiştir. Krizler geçicidir uzun ya da kısa süre sonra sektörlerde toparlanmalar gözlemlenebilir, ancak teknolojik gelişme için aynısını söylemek mümkün değildir. Teknoloji ile ilgili gelişmeler her zaman daha iyiye, daha kârlıya, daha az maliyetliye yönelik olarak gerçekleştirildiği için, bankların insan kaynakları stratejilerinin değiş̧ikliklere uğraması sürpriz olmayacaktır. Latif, Mahmood ve Ali (2020) nitel bir çalışma olarak şekillendirdikleri araștırmalarında, insan kaynakları işlevinin değișen ve gelişen rolünün ortaya çıkan üç temasından söz etmiştir. Ayrıca, elektronik bankacılık uygulamalarının banka çalışanları tarafından algılanması ile ilgili Adelani (2019) tarafindan yapılan Nijerya'da gerçekleştirmiş olduğu araştırmada, elektronik bankacılık ile banka çalışanlarının iş güvenliği arasındaki ilişki incelenmiştir. Veriler, bir anket aracıllğıyla toplanmış ve frekanslar, ortalamalar ve standart sapma gibi tanımlayıcı istatistikler aracıllğıyla analiz edilmiştir. Hipotez testlerinde ise ki kare yöntemi kullanılmıştır. Çalışmanın sonuçlarına göre, elektronik bankacılı̆̆ın benimsenmesinin bankacılık sektöründe doğrudan iş kaybına yol açmadığını göstermiştir. Ancak bu sonuca rağmen, görüşülen katılımcıların çoğu, elektronik bankacılığın artan oranda benimsenmesiyle birlikte öngörülebilir gelecekte iş kaybının mümkün olduğuna inandıklarını belirtmiştir. Aynı şekilde Ahmed ve Rahman (2020)'nin çalışmasında, yeni teknolojilerin dâhil edilmesi ve büyüyen elektronik bankacılık sektörüyle birlikte bankacılık kurumlarında iş gereksinimleri hızla değiştiğinden, banka çalışanlarının bankacılık kurumlarında sahip oldukları iş güvencesi düzeyini bulmak amaçlanmıştır. Çalışma, çalışanların iş güvenliğine yönelik tutumunu ortaya çıkarmak için 7'li Likert ölçekli bir anket kullanılarak gerçekleştirilmiştir. İncelenen değişkenler; otomatik vezne makinesi (ATM), internet bankacılığı hizmetleri, elektronik para transferi ve telefon bankacıllğının, banka çalışanlarının iş güvencelerine yönelik genel tutumu üzerindeki etkisidir. Çalışma, 101 katılımcıdan alınan yanıtları kullanarak SPSS'te regresyon yöntemi kullanılmış ve tüm değişkenlerin negatif bir korelasyon yerine iş güvenliği ile pozitif bir ilişkisi olduğunu keşfetmiştir. Çalışanların gelişen teknoloji nedeniyle iş güvenliklerinden önemli ölçüde etkilenmediği anlaşılmıştır. Çalışma sonucunda, bankaların işe alma politikasını daha fazla teknik işçi istihdam etmeye ve bilgi boşluğunu doldurmak için eğitim programları yürütmeye kaydırmasından kaynaklandığı sonucuna ulaşılmıştır. Çalışmalar bir arada değerlendirildiğinde, çalışanın fonksiyonunun çeşitli yeteneklerle desteklenmesi, dinamik çalışma kültürünü harekete geçirmenin önemi ve çalışanların veri ve teknolojiyi kullanma deneyimine artan odaklanmadır. Görüldüğü üzere, teknolojiyi kullanabilen ve kendisini (eğitim, kurs gibi desteklerle) geliştirebilen çalışanlar bankalar tarafından tercih edilmektedir.

Sonuç olarak, çalışanların kendileri ile ilgili geliştirebilecekleri yönlerin yanında, bankaların da eleman alım sürecinden itibaren uygulama değişikliklerine ihtiyacı bulunmaktadır. Bankalar, azalan şube ve çalışan sayılarına rağmen işe alımlarını sürdürecektir. Ancak işe alımına ağırlık verilecek personellerin, özellikle küresel ölçekte yaşanan salgının da (COVID-19) etkisiyle, teknoloji ile iç içe, yazılım bilgisi olan, uzaktan bağlantılarla evinden çalışabilecek ve yaşanan yeniliklere kolay ve kısa sürede alışabilen özelliklere sahip çalışanlar olması beklenen bir durumdur. Bankacılık sektörü için en önemli konulardan 
biri olan satı̧s ve pazarlama personellerinden de benzer özelliklerin talep edilmesi olasıdır. Konu çerçevesinde, yabancı yazında da rastlanan çalışanlar açısından dijital bankacılık uygulamaları ile ilgili ileriki zaman dönemi içerisinde beklentiler konuları çalışılabilecek konular arasındadır.

\section{Bilgilendirme / Acknowledgement:}

Yazar așağıdaki billgillendirmeleri yapmaktadır:

1- Öğr. Gör. Ali Şimşek hocama desteklerinden dolayı teşekkür ederim.

2- Makalemizde etik kurulu izni ve/veya yasal/özel izin alınmasını gerektiren bir durum yoktur. Çalışmaya esas teşkil eden verileri Türkiye Bankalar Birliği (TBB)'ne ait internet sitesinden alınmıştır.

3- Bu makalede araştırma ve yayın etiğine uyulmuştur.

\section{KAYNAKÇA}

Adelani, T. (2019). Electronic banking and employees' job security in Lafia Nasarawa State, Nigeria. Lafia Journal of Economics and Management Sciences, 4(2), 89-107.

Afshan, S. ve Sharif, A. (2016). Acceptance of mobile banking framework in Pakistan. Telematics and Informatics, (33), 370-387.

Ahmad, R. ve Buttle, F. (2002). Retaining telephone banking customers at frontier bank. International Journal of Bank Marketing, 20(1), 5-16.

Ahmed, O. ve Rahman, B. (2020). Employees of commercial banks learning to unlearn: a case study on the impact of electronic banking in the commercial banks of Bangladesh. International Journal of Business and Technopreneurship, 10(1), 31-50.

Aksoy, E., Akçakanat, Ö. (2019). Bankalarda bireysel kredi riskinin $\operatorname{GM}(1,1)$ modeli ile tahmin edilmesi. Kastamonu Üniversitesi İktisadi ve İdari Bilimler Fakültesi Dergisi, 21(2), 70-98.

Alikhani, E., Azad, N., Mousavi, S. ve Mahmoudzadeh, S. (2013). The role of personal and social characteristics on acceptance of new telephone banking services. Management Science Letters, (3), 2737-2742.

Altunoğlu, A., Atay, H. ve Terlemez, B. (2015). İnsan kaynakları bakış açısından yetenek yönetimi: bankac1lık sektörü uygulama örneği. Marmara Üniversitesi İktisadi ve İdari Bilimler Fakültesi Dergisi, 37(1), 47-70.

Anguelov, C., Hilgert, M. ve Hogarth, J. (2004). U.S. consumers and electronic banking, 1995-2003. USA: Fed. Federal Reserve Bulletin.

Ansaloni, G., Cichella, P., Morelli, C., Alberghini, V., Finardi, E., Guglielmin, A., ..., Stagni, C. (2014). Evaluation of work-related stress in call-center workers: application of a methodology. Giornale Italiano Di Medicina Del Lavoro Ed Ergonomia, 36(1), 32-37.

Arabacı, H. (2018). Türkiye'de bankacılık sektörünün gelişimi (2000-2016). Meriç Uluslararası Sosyal ve Stratejik Araştırmalar Dergisi, 2(3), 25-42.

Ayan, E. (2012). Türk bankacılık sektöründe istihdam analizi ve istihdamın arttırılması olanakları. Business and Economics Research Journal, 3(1), 41-57.

Aydemir, E., Bedir, F. ve Özdemir, G. (2013). Gri sistem teorisi ve uygulamaları: bilimsel yazın taramas1. Süleyman Demirel Üniversitesi İktisadi ve İdari Bilimler Fakültesi Dergisi, 18(3), 187-200. 
Aykaç, B. (1999). Insan kaynakları yönetimi ve insan kaynaklarının stratejik planlanması. Ankara: Nobel Yayınları.

Aytar, O., Yeğen, İ. ve Erdemir, N. (2012, Şubat). Elektronik şube ve elektronik bankacıllk hizmetleri. Uşak Üniversitesi Akademik Bilişism Konferansı. (s. 1-11). Uşak.

Bartel, A. (2004). Human resources management and organizational performance: evidence from retail banking. Industrial and Labor Relations Review, 57(2), 181-203.

Becker, B. ve Huselid, M. (2006). Strategic human resources management: where do we go from here? Journal of Management, 32(6), 898-925.

Büte, M. (2011). Kayırmacılığın çalışanlar üzerine etkileri ile insan kaynakları uygulamaları ilişkisi: Türk kamu bankalarına yönelik bir araştırma. Atatürk Üniversitesi Sosyal Bilimler Enstitüsü Dergisi, 15(1), 383-404.

Cantekinler, M. (2007). Bankacıllk sektöründe performans yönetimi ve özel bir bankada performans yönetimine ilişskin uygulama.Yayımlanmamış yüksek lisans tezi, Selçuk Üniversitesi Sosyal Bilimler Enstitüsü, Konya.

Carmona-Benitez, R.B. ve Nieto, M.R. (2019). SARIMA damp trend grey forecasting model for airline industry. Journal of Air Transport Management, (82), 1-10.

Çerik, Ş. ve Bozkurt, S. (2010). Çalışanları örgütsel sosyalizasyon ve kariyer çapalarına yönelik algılamaları arasındaki ilişkinin incelenmesi ve banka çalışanlarına yönelik bir araştırma. Erciyes Üniversitesi İktisadi ve İdari Bilimler Fakültesi Dergisi, (35), 77-97.

Chang, T., Zivin, J., Gross, T. ve Neidell, M. (2019). The effect of pollution on worker productivity: evidence from call center workers in China. American Economic Journal: Applied Economics, 11(1), 151-172.

Cheng, T., Lam, D. ve Yeung, A. (2006). Adoption of internet banking: an empirical study in Hong Kong. Decision Support Systems, (42), 1558-1572.

Çilan, Ç. A. ve Can, M. (2013). Banka şubelerinin performanslarını etkileyen faktörlerin kanonik korelasyon analizi ile incelenmesi. Dumlupinar Üniversitesi Sosyal Bilimler Dergisi, (EYİ 2013 Özel Say1s1), 285-296.

Daniel, E. ve Storey, C. (1997). On-line banking: strategic and management challenges. Long Range Planning, 30(6), 890-898.

Deng, J.-L. (1982). Control problems of grey systems. Systems and Control Letter, 1(5), 288-294.

Deniz, M. ve Ünal, A. (2007). İnsan kaynaklarının bir fonksiyonu olarak örgütsel kariyer yönetimi ve bir uygulama. E-Journal of New World Sciences Academy, 2(2), 101-109.

Dessler, G. (2020). Human resources management sixteenth edition. Florida: Pearson Education.

Driga, I. ve Isac, C. (2014). E-banking services - features, challenges and benefits. Annals of The University of Petroşani, Economics, 14(1), 49-58.

Edwards, K., Quinn, K., Dalziel, P. ve Jack, M. (1997). Evaluating commercial speech recognition and dtmf technology for automated telephone banking services. The Institution of Electrical Engineers, (4), 1-6.

Erben Yavuz, A. ve Babuşçu, Ş. (2018). Türk bankacılık sektöründe penetrasyon; internet bankacılığı ve mobil bankacılık ürünlerindeki penetrasyonun analizi. Ticari Bilimler Fakültesi Dergisi, 2(1), 24-57.

Erol, İ., Çınar, S. ve Duramaz, S. (2015). Bankaların yeni gelir kaynağı: elektronik bankacılık işlem ücretleri, Türk bankac1lık sektöründe banka karl1lığına etkisi. Abant İzzet Baysal Üniversitesi Sosyal Bilimler Enstitüsü Dergisi, 15(2), 1-21. 
Es, H.A. (2020). Gri tahmin modelleri ile toplam enerji talep tahmini: Türkiye örneği. Gümüşhane Üniversitesi Fen Bilimleri Enstitüsü Dergisi, 10(3), 771-782.

Felix, P. (2014). Prospects and challenges of electronic banking in Ghana: the case of Zenith Bank, Sunyani. International Journal of Advances in Management. Economics and Entrepreneurship, (1), 6-14.

Furst, K., Lang, W. ve Nolle, D. (2002). Internet banking. Journal of Financial Services Research, 22(1/2), 95-117.

Gunson, N., Marshall, D., Morton, H. ve Jack, M. (2011). User perceptions of security and usability of single-factor and two-factor authentication in automated telephone banking. Computers \& Security, (30), 208-220.

Gürbüz, G., Kumkale, İ. ve Oğuzhan, A. (2013, Eylül). Bankac1lık sektöründe personel güçlendirme uygulamalarının örgütsel bağlılığa etkisi: Trakya bölgesi bankalarında araştırma. International Conference on Eurasian Economies 2013. St. Petersburg.

Gürbüz, S. (2011). Stratejik insan kaynakları yönetiminin örgütsel bağl1lığa ve iş tatminine etkisi: insan kaynakları yöneticileri üzerinde bir araştırma. Atatürk Üniversitesi Sosyal Bilimler Enstitüsü Dergisi, 15(2), 397-418.

Gürbüz, S. (2019). AMOS ile Yapısal Eşitlik Modellemesi: temel İlkeler ve Uygulamal Analizler. 1. Baskı. Ankara: Seçkin Yayıncılık.

Halford, V. ve Cohen, H. (2003). Technology use and psychosocial factors in the self-reporting of musculoskeletal disorder symptoms in call center workers. Journal of Safety Research, (34), 167-173.

Hanafizadeh, P., Behboudi, M., Koshksaray, A. ve Tabar, M. (2014). Mobile-Banking adoption by Iranian bank clients. Telematics and Informatics, 31, 62-78.

Hatta, K. ve Liyama, Y. (1991). Ergonomic study of automatic teller machine. International Journal of Human-Computer Interaction, 3(3), 295-309.

HSBC. (2020, 21 10). 6 Ağustos 2020 tarihinde www.hsbc.com.tr: https://www.hsbc.com.tr/hsbchakkinda/insan-kaynaklari/hsbcde-kariyer adresinden erişildi.

Ikram, M., Zang, Q. ve Sroufe, R. (2020). Future of quality management system (ISO 9001) certification: novel grey forecasting approach. Total Quality Management \& Business Excellence, 1-28.

Javed, S.A., Ikram, M., Tao, L. ve Liu, S. (2020). Forecasting key indicators of China’s inbound and outbound tourism: optimistic-pessimistic method. Grey Systems: Theory and Application, 123.

John, O.ve Rotimi, O. (2014). Analysis of electronic banking and customer satisfaction in Nigeria. European Journal of Business and Social Sciences, 3(3), 14-27.

Kaleli, A.R., Ceviz, M.A. ve Erentürk, K. (2014). İçten yanmalı motorların ardışık çevrimlerinde oluşan maksimum basınç verilerinin gri öngörücüler kullanılarak tahmini. Ordu Üniversitesi Bilim ve Teknoloji Dergisi, 4(1), 1-14.

Kayacan, E., Ulutas, B. ve Kaynak, O. (2010). Grey system theory-based models in time series prediction. Expert Systems with Applications, (37), 1784-1789.

Khattab, I., Ahmed, A. ve Al-Magli, O. (2020). The implications of e-banking channels on job security and personal development. Banking \& Financial Studies, (35), 9-39.

Koca, Z. (2018). ATM (otomatik vezne makinası) güvenilirliği ve yapılması gerekenler. IVSS 2018.

Koçak, O. ve Erdoğan, Z. (2011). Bankacılık sektöründe yeni insan kaynakları yönetimi yaklaşımları hakkında bir uygulama. Sosyal Siyaset Konferanslarl, 60(1), 259-283. 
Korkmaz, M., Yücel, A., Germir, H., Gümüş, S., Aytaç, A.ve Karta, N. (2015). Türk bankac1l1k sektöründe atm sorunları ve müşteri memnuniyet algısının uygulamalı bir örneği. Uluslararası Hakemli Ekonomi Yönetimi Araştırmaları Dergisi, (4), 113-140.

Latif, K., Mahmood, N. ve Ali, N. (2020). Exploring sustainable human resource management change in the context of digital banking. Journal of Environmental Treatment Techniques, 8(2), 779-786.

Lawack-Davis, V. (2012). The legal and regulatory framework of mobile banking and mobile payments in South Africa. Journal of International Commercial Law and Technology, 7(4), 318-327.

Lin, J.J., Sun, P.T., Chen, J.J.-R., Wang, L.J., Kuo, H.C., Kuo, W.G. (2010). Applying gray model to predicting trend of textile fashion colors. The Journal of The Textile Institute, 101(4), 360-368.

Lin, W.-R., Wang, Y.-H. ve Hung, Y.-M. (2020). Analyzing the factors influencing adoption intention of internet banking: applying dematel-anp-sem approach. Plos One, 15(2), 1-25.

Lin, Y., Chen, M. ve Liu, S. (2004). Theory of grey systems: capturing uncertainties of grey information. Kybernetes, 33(2), 196-218.

Lin, Y.-H., Chen, C.-Y. ve Hong, L. Y.-C. (2010). Perceived job stress and health complaints at a bank call center: comparison between inbound and outbound services. Industrial Health, (48), 349356.

Liu, S. ve Lin, Y. (2010). Grey systems theory and applications. Chennai: Springer-Verlag Berlin Heidelberg.

Lu, S-L. (2018). Integrating heuristic time series with modified grey forecasting for renewable energy in Taiwan. Renewable Energy, 1-9.

Majumder, T. (2012). Human resource management practices and employees' satisfaction towards private banking sector in Bangladesh. International Review of Management and Marketing, 2(1), 52-58.

Mishra, V. ve Bisht, S. (2013). Mobile banking in a developing economy: a customer-centric model for policy formulation. Telecommunications Policy, (37), 503-514.

Nguyen, H-K. (2020). Combining DEA and ARIMA models for partner selection in the supply chain of Vietnam's construction industry. Mathematics, 8(866), 1-20.

Nguyen, N-T. ve Tran, T-T. (2018). Raising opportunities in strategic alliance by evaluating efficiency of logistics companies in Vietnam: a case of Cat Lai Port. Neural Computing and Applications Forum, 1-12.

Ojeka, S. ve Ikpefan, O. (2011). Electronic commerce, automation and online banking in Nigeria: challenges and benefits. Iranian Journal of Management Studies, 4(2), 29-52.

Ömürbek, V., Akçakanat, Ö. ve Aksoy, E. (2018). Kamu sermayeli bankaların karlılıklarının gri tahmin yöntemi ile değerlendirilmesi. Journal of Social and Humanities Sciences Research, 5(29), 3455-3468.

Ömürbek, V., Aksoy, E. ve Akçakanat, Ö. (2018). Bankaların grup bazlı karlılıklarının gri tahmin yöntemi ile değerlendirilmesi. Mehmet Akif Ersoy Üniversitesi Sosyal Bilimler Enstitüsü Dergisi, 10(23), 75-89.

Önalan, Ö., Başeğmez, H. (2018). Estimation of economic growth using grey cobb-douglas production function: an application for us economy. Business, Economics and Finance -JBEF, 7(2), 178190.

Oruç, K.O. ve Başoğlu Fındık, A. (2020). Gri tahminleme ile Süleyman Demirel üniversitesi ağız diş sağlığı merkezi'nde yatan hasta sayılarının tahmini. Süleyman Demirel Üniversitesi Sosyal Bilimler Enstitüsü Dergisi, (37), 193-212. 
Oruç, K.O. ve Çelik Eroğlu, Ş. (2017). Isparta ili için doğalgaz talep tahmini. Süleyman Demirel Üniversitesi İktisadi ve İdari Bilimler Fakültesi Dergisi, 22(1), 31-42.

Özçelik, M. ve Akçay, V. (2019). Bankacılık sektöründe dijitalleşmenin kariyer platosu ile ilişkisi. Türk ve İslam Dünyası Sosyal Araştırmalar Dergisi, 6(22), 150-163.

Özer Keçe, F., Ömürbek, V., Acar, D. (2016). Gri temelli maliyet tahmini. Süleyman Demirel Üniversitesi İktisadi ve İdari Bilimler Fakültesi Dergisi, 21(2), 453-461.

Öztürk, Z. ve Bilgil, H. (2019). Mathematical estimation of expenditures in the health sector in Turkey with grey modeling. Erciyes Üniversitesi Fen Bilimleri Enstitüsü Dergisi, 35(3), 52-58.

Peevers, G., Douglas, G., Marshall, D. ve Jack, M. (2011). On the role of sms for transaction confirmation with ivr telephone banking. International Journal of Bank Marketing, 29(3), 206223.

Polatoğlu, V. ve Ekin, S. (2001). An empirical investigation of the Turkish consumers' acceptance of internet banking services. International Journal of Bank Marketing, 19(4), 156-165.

Poochada, W. ve Chaiklieng, S. (2015). Ergonomic risk assessment among call center workers. Procedia Manufacturing, (3), 4613 - 4620.

Prakash, O. (2015). Human resource management in banking sector. Anusandhanika, 7(1), 95-99.

QNB-Finansbank. (2020, 21 10). www.qnbfinansbank.com. 6 Ağustos 2020 tarihinde https://www.qnbfinansbank.com/insan-kaynaklari/insan-kaynaklari-politikalari/ise-alim-vekariyer-yonetimi adresinden erişildi.

Rahi, S., Ghani, M. ve Ngah, A. (2020). Factors propelling the adoption of internet banking: the role of e-customer service, website design, brand image and customer satisfaction. International Journal of Business Information Systems, 33(4), 549-569.

Rogers, W. ve Walker, N. (1996). A survey of automatic teller machine usage across the adult life span. Human Factors, 38(1), 156-166.

Roy, A. (2018). Business impacts of electronic banking technologies. Int. J. Electronic Banking, 1(2), 113-128.

Safeena, R., Date, H., Kammani, A . ve Hundewale, N. (2012). Technology adoption and Indian consumers: study on mobile banking. International Journal of Computer Theory and Engineering, 4(6), 1020-1024.

Şahin, E.E. ve Bağc1, B. (2020). Kripto para fiyatlarının tahmininde gri sistem teorisi: yöntemsel karşılaştırma. Anadolu Üniversitesi Sosyal Bilimler Dergisi, 20(1), 219-232.

Şahin, T. (2019). Ruh sağlığı ve hastalıkları polikliniğine olan talebin zaman serileri modelleri ile tahmini. Hacettepe Să̆llk İdaresi Dergisi, 22(4), 749-764.

Şahin, U. (2018). Forecasting of Turkey's electricity generation and consumption with Grey prediction method. Mugla Journal of Science and Technology, 4(2), 205-209.

Sardana, V. ve Singhania, S. (2018). Digital technology in the realm of banking: a review of literature. International Journal of Research in Finance and Management, 1(2), 28-32.

Shaikh, A. ve Karjaluoto, H. (2015). Mobile banking adoption: a literature review. Telematics and Informatics, (32), 129-142.

Siam, A. (2006). Role of the electronic banking services on the profits of Jordanian banks. American Journal of Applied Sciences, 3(9), 1999-2004.

Sri, D. ve Panchanatham, N. (2012). Health issue leads to employee attrition in Chennai based call center industry. International Journals of Marketing and Technology, 2(5), 210-218. 
Sundarraj, R. ve Wu, J. (2005). Using information-systems constructs to study online- and telephonebanking technologies. Electronic Commerce Research and Applications, (4), 427-443.

Taşçı, L. (2017). Çok Değişkenli Gri Sistem Teorisi ile Deformasyon Tahmini. Fırat Üniversitesi Mühendislik Bilimleri Dergisi, 29(1), 277-283.

Teka, B. (2017). Assessment of the practices and challenges of electronic banking adoption in Ethiopia. International Journal of Research in It and Management, 7(3), 82-94.

Tondre, A. (2015). Human resource management in banking sector. International Journal for Administration in Management. Commerce and Economics, (3), 130-137.

Tran, T-T. (2018). Building forecasting model of automobile industry based on Grey theory: A case study of Nissan motor corporation. International Journal of Advanced and Applied Sciences, 5(10), 7-15.

Türkiye Bankalar Birliği. (2020, 09 22). www.tbb.org.tr. 6 Ağustos 2020 tarihinde https://www.tbb.org.tr/tr/bankacilik/banka-ve-sektor-bilgileri/istatistiki-raporlar/59 adresinden erişildi.

Ural, A. ve Kılıç, İ. (2013). Bilimsel araştırma süreci ve spss ile veri analizi. 4. Baskı. Ankara: Detay Yayıncilik.

Uzundağ, Ş. (2013). Türkiye'de internet bankactlı̆ğnın gelişsimi ve internet bankacılı̆̆ına ilişskin tüketici davranışları analizi. Yayımlanmamış yüksek lisans tezi, Adnan Menderes Üniversitesi Sosyal Bilimler Enstitüsü İşletme Anabilim Dalı, Aydın.

Wang, Q., Liu, S., Yan, H. (2018). The application of trigonometric grey prediction model to average per capita natural gas consumption of households in China. Grey Systems: Theory and Application, 6, 1608-1618.

Yıldırım, B.F., Keskintürk, T. (2015). Kredi kartı kullanım istatistiklerinin gri tahmin ve genetik algoritma tabanlı gri tahmin metodu ile tahmini: karşılaştırmalı analiz. Bankacılar Dergisi, 94, 65-80.

Yıldız, S. (2011). Entelektüel sermayenin işletme performansına etkisi: bankacılık sektöründe bir araştırma. Anadolu Üniversitesi Sosyal Bilimler Dergisi, 11(3), 11-28.

Yurdatapan, S. (2011). Türk bankacıllk sektöründe insan kaynakları yönetimi uygulamalarını belirlemeye yönelik bir araştırma. Yayımlanmamış yüksek lisans tezi, Trakya Üniversitesi Sosyal Bilimler Enstitüsü Çalışma Ekonomisi ve Endüstri İlişkileri Anabilim Dalı, Edirne.

Yurttadur, M. ve Süzen, E. (2016). Türkiye'de banka müşterilerinin internet bankacıllı̆ğıa yaklaşımlarının incelenmesi üzerine bir uygulama. Tüketici ve Tüketim Araştırmaları Dergisi, 8(1), 93-120.

Zeng, B., Li, S., Meng, W. ve Zhang, D. (2019). An improved gray prediction model for China’s beef consumption forecasting. Plos One, 14(9), 1-18.

Zhao, L. ve Zhou, X. (2018). Forecasting electricity demand using a new grey prediction model with smoothness operator. Symmetry, 10(693), 1-13.

Ziraatbank. (2020, 21 10). $\quad$ www.ziraatbank.com.tr. 6 Ağustos 2020 tarihinde https://www.ziraatbank.com.tr/tr/bankamiz/insan-kaynaklari/ziraatli-olmak adresinden erişildi.

Zor, C. ve Çebi, F. (2018). Demand prediction in health sector using fuzzy grey forecasting. Journal of Enterprise Information Management, 31(6), 937-949. 